\title{
Hydrogeochemistry of Water Resources of Oka Municipality
}

\author{
Cyril C. Okpoli \\ Department of Earth Sciences, Adekunle Ajasin University, Akungba-Akoko, Ondo State, Nigeria. \\ Email: cyril.okpoli@aaua.edu.ng
}

\begin{abstract}
The absence of Perennial River, semi-arid climatic condition and growing neediness of water increased the usage of water resources. In Oka municipality, all the water resources characters are sampled for its chemistry. Hydrochemistry of the water is influenced by geogenic and anthropogenic sources. Hence to assess the chemical characteristics of the water in the study area, a total of 20 water samples from different sources were collected and analyzed for physical parameters such as $\mathrm{pH}$, conductivity and Total Dissolved Solids along with major cations and anions using standard procedures. The dominant cations and anions were, $\mathrm{Na}>\mathrm{Ca}>\mathrm{Mg}>\mathrm{K}$ and $\mathrm{HCO}>\mathrm{Cl}>$ $\mathrm{NO} 3>\mathrm{F}>\mathrm{PO} 4>\mathrm{SO} 4$ respectively. Hydro chemical facies demarcated were $\mathrm{NaCl}, \mathrm{CaNaHCO}_{3}$, $\mathrm{CaHCO}_{3}$ and $\mathrm{CaMgCl}$. The facies suggests ionic exchange, dissolution, silicate weathering and anthropogenic sources are responsible for the variation in water chemistry of the study area. The silicate group minerals show over equilibrium conditions sulphate and halide group minerals indicate under saturation condition. Stiff diagrams are used to distinguish the water types. Box and whisker plots and rank sum tests confirm that the five water types are distinct from each other. The three water types cluster together in three separate areas. Piper plots indicate that considerable cation exchange has occurred in the $\mathrm{NaHCO}_{3}$. The Ca-rich recharge water exchanges $\mathrm{Ca}$ for $\mathrm{Na}$ and $\mathrm{K}$, producing the $\mathrm{NaHCO}_{3}$. The saturation values trend increases along the flow path.
\end{abstract}

Keywords: Hydrogeochemistry, Oka, Municipality, water resources, facies.

\section{Introduction}

Water resources are essential drinking water resource in developing cities, particularly in places where no public water supply exists because of an insufficient infrastructure or a poor economic situation. Shortage of water is one of the main problems that many societies face due to the unequal distribution of resources, in addition to man-induced pollution (agricultural and urbanization activities), and unsustainable or improper management of the water resources. Groundwater is the chief source of fresh water supply in many countries and it makes up about ninety percent of the world's readily available freshwater resource. Therefore, assessment of its occurrence, distribution, potentiality and quality is of a great concern to public and local authorities. According to Botkin and Keller (1998), more than 97\% of earth's water is in the oceans and ice caps, and glaciers account for another $2 \%$. Also, the ocean comprises $97 \%$, while $3 \%$ of the earth's water is fresh (Kulshreshtha, 1998). Water in its pure state is acclaimed key to health and the general contention is that water is more basic than all other essential things to life (Edungbola and Asaolu, 1984). Man requires a regular and accessible supply of water which forms a major component of the protoplasm and provides an essential requirement for vital physiological and biochemical processes. Man can go without food for twenty eight days, but only three days without water, and two third of a person's water consumption per day is through food while one third is obtained through drinking (Muyi, 2007).

Water resources are of critical importance to both natural ecosystem and human development. It is essential for agriculture, industry and human existence. The healthy aquatic ecosystem depends on the physico-chemical and biological characteristics (Venkatesharaju et al 2010). The quality of water in any ecosystem provides significant information about the available resources for supporting life in that ecosystem. Good quality of water resources depends on a large number of physico-chemical parameters and biological characteristics.

Basic household water requirements have been suggested at 50 litres per person per day excluding water to gardens (Boss, 2004). (Batmanghelid, 2009) reported that since the water we drink provides for cell function and its volume requirements, the decrease in our daily water intake affects the efficiency of 
cells and other body activities. In addition to human consumption and health requirements, water is also needed in agriculture, industrial, recreational and other purposes. Water is also considered a purifier in most religions (Foel and Nennewan, 1986). Though all these needs are important, water for human consumption and sanitation is considered to be of greater social and economic importance since health of the population influences all other activities. According to (Odiette, 1999), environmental water usage includes artificial wet lands, artificial lakes intended to create wildlife habitat, fish ladders around dams and water releases from reservoirs to help fish spawn. Ground water is the water beneath the surface where all the voids in the rocks and soil are filled. It is a source of water for wells, boreholes and springs.

A borehole is a hydraulic structure which when properly designed and constructed, permits the economic withdrawal of water from an aquifer. It is a narrow well drilled with machine. Borehole water is the water obtained from borehole drilled into the aquifer or ground water zone, which is usually a fully saturated subterranean zone, some distance below the water table (NWRI, 2002). Ground water is already used extensively in Nigeria through wells and boreholes. Unfortunately borehole water like water from other sources is never entirely pure. It varies in purity depending on the geological conditions of the soil through which the ground water flows and some anthropogenic activities. Until very recently, ground water has been thought of as being a standard of water purity in itself, and to a certain extent, that is indeed true (Miller, 1992). Apart from the essential role played by water in supporting human life, it also has, if polluted, a great potential for transmitting a wide variety of diseases. In most developing countries like Nigeria where dangerous and highly toxic industrial and domestic wastes are disposed of by dumping them on the earth; into rivers and streams with total disregard for aquatic lives and rural dwellers, water becomes an important medium for the transmission of enteric diseases in most communities. Poisonous chemicals are known to percolate the layers of the earth and terminate in ground waters thereby constituting public health hazards. In Oka Akoko area, certain anthropogenic activity like the improper waste disposal can contribute to ground water pollution. This area suffers from non-provision of potable water supply. The inhabitants are therefore depending largely on borehole water supply which is of doubtful quality.

Public water supply in the area under study is grossly inadequate and the inhabitants have been compelled to depend on borehole water supply whose quality is doubtful. Consumption of such water can cause water borne diseases such as typhoid and paratyphoid fevers (salmonellosis) as most of the enteric diseases are transmitted through water. Other principal microbial water borne diseases include cholera, bacillary dysentery (shigellosis) and infectious hepatitis.

Recently, the development activities in Oka municipality have expanded dramatically towards the neighbouring zones where new educational centres and commercial zones, urban centres on reclaimed land, including new villages have been established. Uncontrolled urbanization has taken place creating pressure on the abstracted groundwater aquifer systems as they are the main sources for water. Few authors have investigated the water resources potentiality in the study area and its surroundings and have not dealt with the factors influencing hydrogeochemistry of the groundwater (Jayeola, 2014; Ogunribido and kehinde Phillips 2011; Elueze 1997). The principal aim of this study is to determine the factors influencing the groundwater geochemistry using hydrogeochemical signatures of the major ions employing the statistical analysis techniques.

\section{Geological and Hydrological Setting}

The study area, Oka Akoko municipality, Ondo State Nigeria, which is part of Precambrian basement complex of southwestern Nigeria and Nigerian basement complex (Figs.1-3). The basement complex rocks of south-western Nigeria are composed predominantly of migmatite and granite gneisses, quartzite, slightly migmatized to unmigmatized metasedimentary schist and meta-igneous rocks; charnochitic, gabbroic and dioritic rocks and members of the older granite suite mainly granites, granodorites and syenites (Rahaman, 1976, 1978, 1988).

It is located sub-tropical (tropical hinterland) climatic regions of Nigeria. There are two characteristics of the seasons in this area; these include the rainy season (wet) and dry season. The wet season starts from April, and ends around mid-October. The dry season begins in mid-October; it extends through February and ends towards the end of March. The highest mean annual rainfall is usually experienced in July/August. The wet season is characterized by the temperature range of $27^{0} \mathrm{c}$ to 
$37^{\circ} \mathrm{c}$ whereas dry season is typical of mean temperature $35^{\circ} \mathrm{C}$. The relative humidity is about $73 \%$ from November to March and approximately $90 \%$ around August.

The mean annual rainfall is $1397 \mathrm{~mm}$ while the mean annual temperature is about $26^{\circ} \mathrm{c}$. The vegetation type is forest savannah mosaic of moist lowland vegetation belt of Nigeria (Federal surveys, 1978). The vegetation is typified by wooden shrubs, moist semi-deciduous trees, oil palms found on basement highs, and well developed herbaceous plant found in valley. However, human interference through infrastructural development has modified the original vegetation.

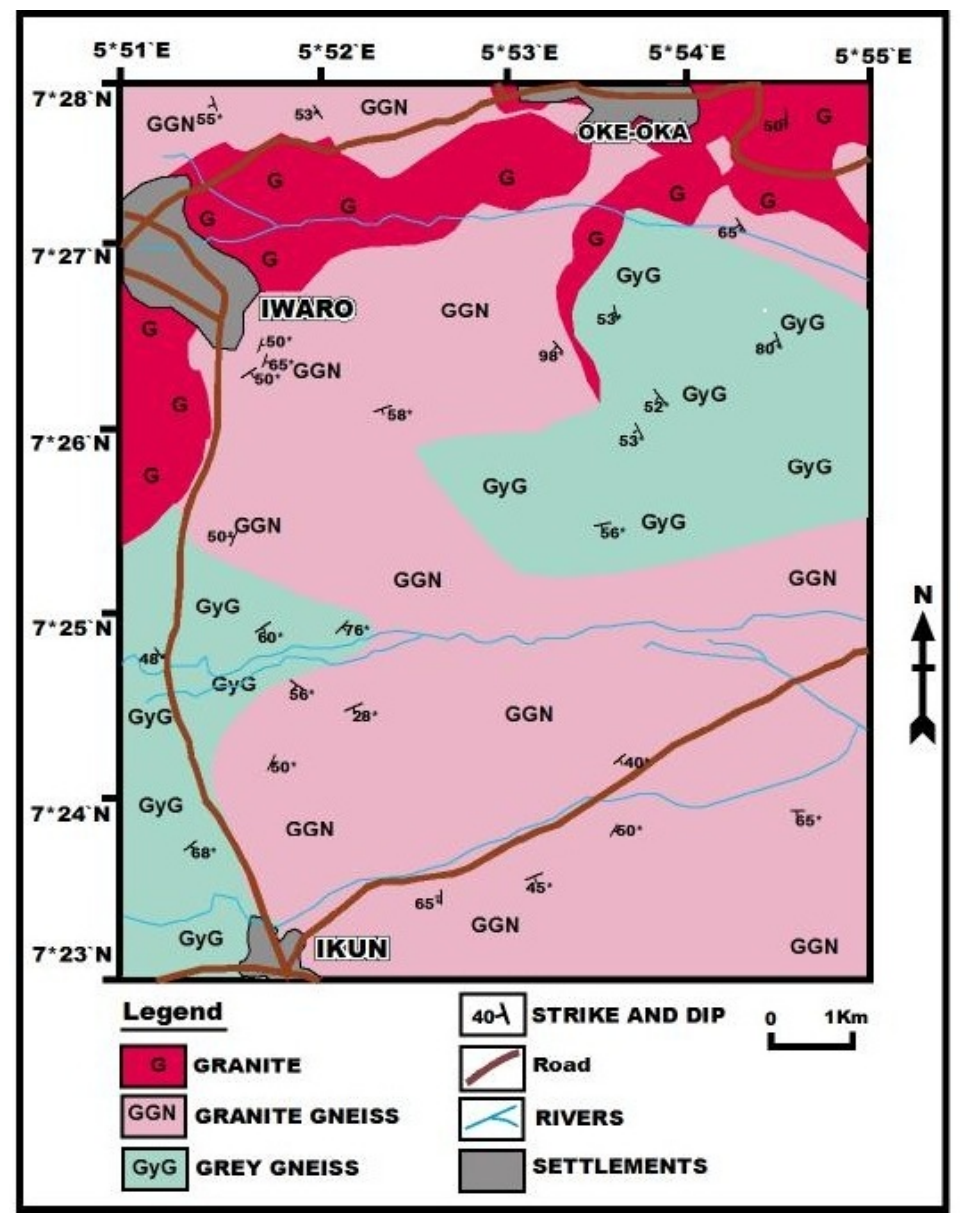

Figure 1. Geological map of the study area. (Source: Geological Survey of Nigeria).

The crystalline basement rocks are general) massive and impermeable; the boundary between the weathered layer and the fresh basement bedrock is rarely sharp. Most often a transition zone, referred to by Mcfarlane (1989) as the sap rock exists between the weathered layer and the fresh basement. In a typical basement complex environment, the transition zone has been identified as a very important lithologic unit which carries significantly to the prolificity and yields of groundwater boreholes. Because of its enhanced permeability due to secondary porosity, the transition zone complements the weathered layer of groundwater storage and yields. This zone of fracturing below the saprolite (transition zone) earlier discussed forms an aquifer in addition to the overlying weathered layer (Saprolite). This aquifer combination is called weathered/fractured (unconfmed) aquifer Olorunfemi and Fasuyi, 1993) 


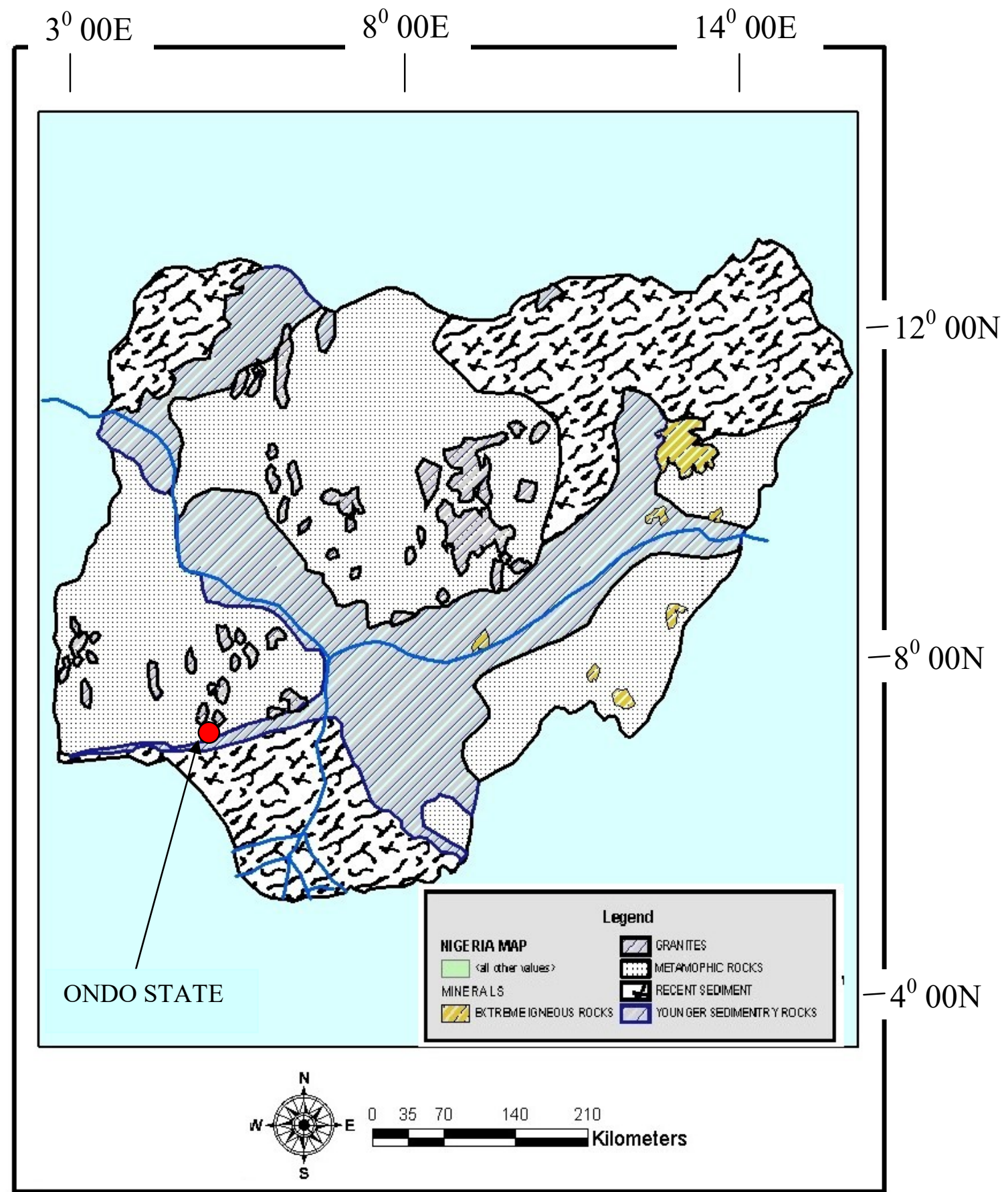

Figure 2. Geological map of Nigeria showing Basement complex (Source: Ajibade et al., 1989)

\section{Materials and Methods}

\section{Sampling and analytical procedures}

Water resources samples were collected in May 2015 from 5 stagnant water, 5 boreholes, 5 handdug wells and 5 stream wells distributed in Oka municipality. The water samples were collected and stored in polyethylene bottles of 1.5 -L capacity and preserved at $4{ }^{\circ} \mathrm{C}$ until analysis. The bottles were rinsed several times with deionized water followed by three times with the water resources samples to be sampled prior to their filling with water samples to minimize the chance of any contamination. Sample 
preservation and analytical techniques used were in accordance with the standard methods from American Public Health Association (APHA, 2005). Hydrogen ion concentration ( $\mathrm{pH}$ ), total dissolved solids (TDS), and electrical conductivity (EC) of the water samples were measured in the field using a pH-meter, a portable EC-meter, and a TDS meter (Hanna Instruments, Michigan, USA).

Levels of sodium $\left(\mathrm{Na}^{2+}\right)$, potassium $\left(\mathrm{K}^{+}\right)$, calcium $\left(\mathrm{Ca}^{2+}\right)$, and magnesium $\left(\mathrm{Mg}^{2+}\right)$ ions were determined by Atomic Absorption Spectroscopy and Flame Photometry (Perkin-EImer Corporation) following the methods of APHA (2005). Concentrations of bicarbonate $\left(\mathrm{HCO}_{3}^{-}\right)$and chloride $\left(\mathrm{Cl}^{-}\right)$were determined by titration, while that of sulfate $\left(\mathrm{SO}_{4}{ }^{2-}\right)$ was measured by colorimetric and turbidimetric methods APHA (2005).

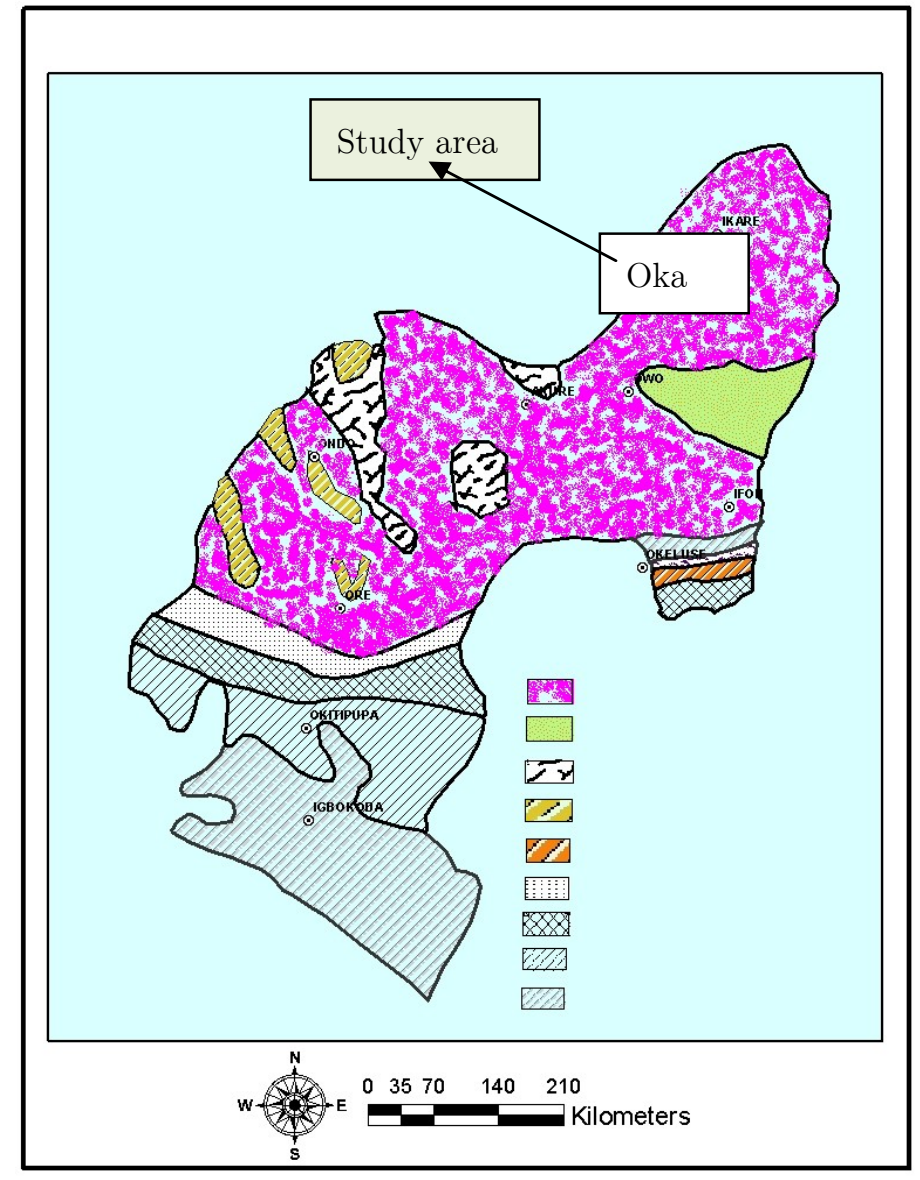

Figure 3. Map of Ondo State Showing Area of Study. Modified from GSN, Ondo State,(2001).

\subsection{Statistical Procedures and Factor Analysis (FA)}

Statistical analysis, box plot analysis and factor analysis of the groundwater hydrochemistry data were performed using the EXCEL software. Factor analysis of chemical data was used to formulate the data to an easily interpretable form and to enable identification of the natural processes and anthropogenic inputs to the chemical composition of groundwater in the area ( Jiang et al., 2007). The variables used for the statistical analysis were $\mathrm{pH}, \mathrm{EC}, \mathrm{HCO}_{3}{ }^{-}, \mathrm{Ca}^{2+} \mathrm{Mg}^{2+}, \mathrm{Na}^{+}, \mathrm{K}^{+}, \mathrm{SO}_{4}{ }^{2-}$, and $\mathrm{Cl}^{-}$. The first step in the statistical analysis is the computation of the sum, maximum, minimum, mean and correlation matrix that needs a normal distribution of all variables. The EXCEL software was used to get the covariance pearson product moment, skewness, standard deviation, variance and regresssion. By statistical analysis the factor loadings, communalities and eigenvalues, different variables belonging to a specific chemical process can be recognized, and as a result the importance of the major elements can be 
evaluated in relation to the whole data set. Communality is the variance of that variable as determined by the common factors. Spatial distributions of factor scores were interpolated by ordinary kriging and accomplished using SURFER 12 software to evaluate the areal importance of the chemical process represented by that factor.

\section{Results Discussions}

\subsection{Hydrogeochemical Characteristics of the Water Resources}

The geochemical compositions of collected spring and other water samples are shown in Table 1 . The $\mathrm{pH}$ of various water resources varied from 7.35 to 8.5 and had the mean of 7.98 , however, in most samples the water resources standard deviation and skewness were 0.377 and 3.063 respectively. The electrical conductivity (EC) values varied from 68.9 to $23.2 \mathrm{lS} \mathrm{cm}^{1}$ and had the mean of 47.75 as well as the standard deviation of 13.806968 and skewness of 0.49131613. Maximun, minimum, mean, standard deviation and skewness of Temperatures, Turbidity, TDS, Pb, Fe, Cr, Ni, Cd, Cu of water resources varied between $28,26,27.05,3.176 ; 0.762,0.063,0.1586,0.21348,2.249763 ; 0.896,0.85,0.8764,0.017$, $1.613 ; 0.1,0.01,0.04,0.01,1.732 ; 0.05,0.01,0.033,0.02,0.935 ; 0.01,0.01,0.01,0.01 ; 0.04,0,0.02,0.01$, 0.94; 0.017, B/D, 0.017, 0.017; 0.02, 0.01, 0.13, 0.01, 1-732 respectively but Chromiun (Cr) and Cadmiun (Cd) are not skewed.

The Sum and Mean of anions and cations e.g $\mathrm{K}^{+}, \mathrm{Ca}^{2+}$, and $\mathrm{Mg}^{2+}, \mathrm{Na}^{2+}$ and $\mathrm{HCO}_{3}^{-}, \mathrm{Cl}^{-}, \mathrm{SO}_{4}{ }^{2-}$ varies from 422.94, 683.17, 827.8, 362.8, 4636.8, 2646.71, 5.55 and 21, 147, 34.16, 41.39, 18.14, 231.84, 132.3355, 0.2775 respectively. Correlation between $\mathrm{K}^{+}$and $\mathrm{Ca}^{2+}, \mathrm{Mg}^{2+}$, and $\mathrm{Na}^{2+} \mathrm{HCO}^{-}$and $\mathrm{Cl}^{-}$are: 0.189207 , 0.19384 and 0.058 respectively. Covariance between $\mathrm{K}^{+}$and $\mathrm{Ca}^{2+}, \mathrm{Mg}^{2+}$, and $\mathrm{Na}^{2+} \mathrm{HCO}_{3}^{-}$and $\mathrm{Cl}^{-}$are: 8,674566, 34.97224 and 330.7645 respectively. Pearson product moment between $\mathrm{K}^{+}$and $\mathrm{Ca}^{2+}, \mathrm{Mg}^{2+}$, and $\mathrm{Na}^{2+} \mathrm{HCO}_{3}^{-}$and $\mathrm{Cl}^{-}$are: $0.189207,0.19384,0.058$ respectively. Skewness between $\mathrm{K}^{+}$and $\mathrm{Ca}^{2+}, \mathrm{Mg}^{2+}$, and $\mathrm{Na}^{2+} \mathrm{HCO}_{3}^{-}$and $\mathrm{Cl}^{-}$are: 0.843437, 0.07193, and 1.078646 respectively. Standard Deviation between $\mathrm{K}^{+}$and $\mathrm{Ca}^{2+}, \mathrm{Mg}^{2+}$, and $\mathrm{Na}^{2+} \mathrm{HCO}_{3}^{-}$and $\mathrm{Cl}^{-}$are: $10.15368,18.56607$ and 94.47276 respectively. Variance between $\mathrm{K}^{+}$and $\mathrm{Ca}^{2+}, \mathrm{Mg}^{2+}$, and $\mathrm{Na}^{2+} \mathrm{HCO}_{3}^{-}$and $\mathrm{Cl}^{-}$are: 103.0973, 344, 699 and 8925.103 respectively. Regression between $\mathrm{K}^{+}$and $\mathrm{Ca}^{2+}, \mathrm{Mg}^{2+}$, and $\mathrm{Na}^{2+}, \mathrm{HCO}_{3}^{-}$and $\mathrm{Cl}^{-}$are: 8.151163, 15.702 and 72.43114 respectively as observed in Table1 and 2 .

Exceptionally high values of all Chloride anion were observed at the location WELL 1, STRM 2 and BH5 (Table 1). Among the major cations in the water resources, $\mathrm{Na}^{2+}$ and $\mathrm{Ca}^{2+}$ dominated and accounted for more than $60 \%$ of the total cation concentrations. The mean $\mathrm{Ca}^{2+}, \mathrm{Mg}^{2+}, \mathrm{Na}^{2+}$ and $\mathrm{K}^{+}$ values $( \pm 1 \mathrm{r})$ were $(34.2 \pm 25) \mathrm{mg} / \mathrm{l},(18 \pm 12) \mathrm{mg} / \mathrm{l},(41.2 \pm 5.0) \mathrm{mg} / \mathrm{l}$ and $(21.2 \pm 1.0) \mathrm{mg} / \mathrm{l}$, respectively. Overall, water resources in the region belong to the $\mathrm{Na}^{-\mathrm{HCO}^{3-}}$ type (Table 1). Molar ratios of major elements in groundwater are widely used for evaluating water-rock interactions. Even though soldic and calcic feldspars is generally more difficult to dissolve and despite the fact that this process should be even more hampered in metamorphic terrain, the high $\mathrm{Na}^{2+} / \mathrm{Ca}^{2+}$ molar ratios of nearly 0.9 in the water resources of our study indicate dominant Feldspars weathering.

Table 1. Results and statistical analyses of the chemical parameters of groundwater in the study area.

\begin{tabular}{|l|l|l|l|l|l|l|l|}
\hline Resource Type & $\begin{array}{l}\mathbf{K}^{+} \\
(\mathbf{m g} / \mathbf{l})\end{array}$ & $\begin{array}{l}\mathrm{Ca}^{2+} \\
(\mathbf{m g} / \mathbf{l})\end{array}$ & $\mathbf{N a}^{2+}$ & $\begin{array}{l}\mathbf{M g}^{2+} \\
(\mathbf{m g} / \mathbf{l})\end{array}$ & $\mathbf{H C O}_{3}{ }^{-}$ & $\mathbf{C l}^{-}$ & $\begin{array}{l}\mathbf{S O}_{4}{ }^{2-} \\
(\mathbf{m g} / \mathbf{l})\end{array}$ \\
\hline WELL 1 & 19.26 & 29.26 & 47.22 & 2.92 & 122 & 209.16 & 0.23 \\
\hline WELL 2 & 12.69 & 31.26 & 31.4 & 10.45 & 122 & 159.53 & 0.12 \\
\hline WELL 3 & 21.33 & 29.65 & 40.26 & 0.73 & 244 & 92.17 & 0.1 \\
\hline WELL 4 & 25.12 & 31.66 & 28.5 & 6.8 & 158.6 & 99.26 & 0.39 \\
\hline WELL 5 & 18.25 & 42.5 & 32.47 & 17.5 & 225.7 & 113.44 & 0.17 \\
\hline STG 1 & 21.37 & 40.5 & 62.35 & 60.26 & 500.2 & 172.29 & 1.02 \\
\hline STG 2 & 22.45 & 56.51 & 60.25 & 24.54 & 402.6 & 109.89 & 1 \\
\hline STG 3 & 32.16 & 40.9 & 42.12 & 1.94 & 195.2 & 127.62 & 0.81 \\
\hline STG 4 & 23.27 & 23.65 & 46.1 & 2.19 & 134.2 & 116.99 & 0.08 \\
\hline
\end{tabular}




\begin{tabular}{|l|l|l|l|l|l|l|l|}
\hline STG 5 & 21.55 & 18.43 & 50.28 & 3.88 & 140.3 & 56.72 & 0.21 \\
\hline STRM 1 & 23.45 & 35.3 & 37.63 & 9.23 & 122 & 109.89 & 0.15 \\
\hline STRM 2 & 25.26 & 50.1 & 57.11 & 46.66 & 207.1 & 251.69 & 0.08 \\
\hline STRM 3 & 22.12 & 44.1 & 46.23 & 10.94 & 300 & 155.98 & 0.02 \\
\hline STRM 4 & 22.68 & 32.1 & 39.42 & 10.21 & 201.3 & 99.26 & 0.08 \\
\hline STRM 5 & 26.42 & 38.1 & 48.18 & 10.21 & 268.4 & 120.53 & 1.02 \\
\hline BH 1 & 23.25 & 16.03 & 31.05 & 4.86 & 244 & 17.73 & 0.02 \\
\hline BH 2 & 19.25 & 24.1 & 27.42 & 38.88 & 237.9 & 191.43 & 0.02 \\
\hline BH 3 & 16.2 & 32.1 & 25.6 & 38.88 & 280.6 & 24.82 & 0.01 \\
\hline BH 4 & 10.68 & 33.26 & 42.06 & 23.81 & 268.4 & 198.52 & 0.01 \\
\hline BH 5 & 16.18 & 33.66 & 32.15 & 37.91 & 262.3 & 219.79 & 0.01 \\
\hline SUM & 422.94 & 683.17 & 827.8 & 362.8 & 4636.8 & 2646.71 & 5.55 \\
\hline MEAN & 21.147 & 34.1585 & 41.39 & 18.14 & 231.84 & 132.3355 & 0.2775 \\
\hline CORRELATION & 0.189207 & & 0.19384 & & 0.058 & & \\
\hline COVARIANCE & 8.674566 & & 34.97224 & & 330.7645 & & \\
\hline PEARSON PRODUCT MOMENT & 0.189207 & & 0.19384 & & 0.058 & & \\
\hline SKEWNESS & 0.843437 & & -0.07193 & & 1.078646 & & \\
\hline STANDARD DEVIATION & 10.15368 & & 18.56607 & & 94.47276 & & \\
\hline VARIANCE & 103.0973 & & 344.699 & & 8925.103 & & \\
\hline REGRESSION & 8.151163 & & 15.702 & & 72.43114 & & \\
\hline
\end{tabular}

Table 2. Results and statistical analyses of the chemical parameters of groundwater in the study area.

\begin{tabular}{|c|c|c|c|c|c|c|c|c|c|c|c|}
\hline $\begin{array}{l}\text { Resource } \\
\text { type }\end{array}$ & $\begin{array}{l}\mathrm{pH} \\
\text { value }\end{array}$ & $\begin{array}{l}\text { Electrical } \\
\text { Conductivity }\end{array}$ & Temp. & Turbidity & $\begin{array}{l}\text { TDS } \\
(\mathrm{mg} / \mathrm{l})\end{array}$ & $\mathrm{Pb}$ & $\mathrm{Fe}$ & $\mathrm{Cr}$ & $\mathrm{Ni}$ & $\mathrm{Cd}$ & $\mathrm{Cu}$ \\
\hline HDW 1 & 7.45 & 30.9 & 26 & 0.063 & 0.873 & 0.02 & 0.01 & 0.01 & 0.1 & $\mathrm{~B} / \mathrm{D}$ & 0.04 \\
\hline HDW 2 & 7.6 & 51.3 & 27 & 0.063 & 0.869 & 0.02 & 0.01 & 0.01 & 0.1 & $\mathrm{~B} / \mathrm{D}$ & 0.01 \\
\hline HDW 3 & 7.76 & 39.6 & 27 & 0.084 & 0.908 & $\mathrm{~B} / \mathrm{D}$ & 0.02 & $\mathrm{~B} / \mathrm{D}$ & 0.1 & $\mathrm{~B} / \mathrm{D}$ & 0.01 \\
\hline HDW 4 & 8.41 & 55.6 & 27 & 0.091 & 0.883 & 0.01 & 0.01 & $\mathrm{~B} / \mathrm{D}$ & 0.1 & $\mathrm{~B} / \mathrm{D}$ & 0.02 \\
\hline HDW 5 & 8.22 & 60.7 & 27 & 0.083 & 0.872 & 0.02 & 0.01 & $\mathrm{~B} / \mathrm{D}$ & 0.1 & 0.01 & 0.01 \\
\hline STG 1 & 8.44 & 68.9 & 26 & 0.082 & 0.884 & 0.04 & 0.02 & 0.01 & 0.1 & 0.01 & 0.04 \\
\hline STG 2 & 8.02 & 62.6 & 27 & 0.148 & 0.892 & 0.06 & 0.87 & 0.01 & 0.2 & $\mathrm{~B} / \mathrm{D}$ & 0.05 \\
\hline STG 3 & 7.66 & 44.2 & 28 & 0.519 & 0.898 & 0.07 & 4.91 & 0.01 & 0.2 & $\mathrm{~B} / \mathrm{D}$ & 0.12 \\
\hline STG 4 & 7.35 & 33 & 26 & 0.762 & 0.899 & 0.1 & 5.02 & 0.01 & 0.10 & 0.01 & 0.15 \\
\hline $\begin{array}{l}\text { STG } 5 \\
\end{array}$ & 7.8 & 23.2 & 26 & 0.144 & 0.89 & 0.2 & 4.03 & $\mathrm{~B} / \mathrm{D}$ & 0.8 & 0.01 & 0.09 \\
\hline $\begin{array}{l}\text { STRM } 1 \\
\end{array}$ & 8.4 & 34.8 & 27 & 0.088 & 0.903 & $\mathrm{~B} / \mathrm{D}$ & 0.04 & 0.01 & 0 & $\mathrm{~B} / \mathrm{D}$ & 0.01 \\
\hline STRM 2 & 8.28 & 30.2 & 27 & 0.312 & 0.878 & 0.1 & 0.23 & $\mathrm{~B} / \mathrm{D}$ & 0.2 & 0.01 & 0.02 \\
\hline STRM 3 & 8.1 & 54.2 & 28 & 0.177 & 0.877 & 0.05 & 0.22 & $\mathrm{~B} / \mathrm{D}$ & 0.2 & 0.02 & 0.01 \\
\hline STRM 4 & 7.77 & 52.1 & 27 & 0.089 & 0.881 & 0.01 & 0.1 & 0.01 & 0.1 & 0.01 & 0.01 \\
\hline STRM 5 & 8.2 & 28.9 & 27 & 0.118 & 0.893 & 0.1 & 4.8 & 0.01 & 0.1 & 0.01 & 0.08 \\
\hline BH 1 & 7.62 & 46.5 & 27 & 0.062 & 0.879 & $\mathrm{~B} / \mathrm{D}$ & 0.01 & $\mathrm{~B} / \mathrm{D}$ & 0 & $\mathrm{~B} / \mathrm{D}$ & 0.01 \\
\hline$\overline{\mathrm{BH}} 2$ & 8.4 & 58.7 & 28 & 0.06 & 0.896 & $\mathrm{~B} / \mathrm{D}$ & 0.01 & $\mathrm{~B} / \mathrm{D}$ & 0 & $\mathrm{~B} / \mathrm{D}$ & 0.01 \\
\hline$\overline{\mathrm{BH}} 3$ & 7.72 & 59.5 & 28 & 0.086 & 0.852 & 0.01 & 0.02 & $\mathrm{~B} / \mathrm{D}$ & 0 & $\mathrm{~B} / \mathrm{D}$ & 0.02 \\
\hline$\overline{\mathrm{BH}} 4$ & 7.5 & 56.2 & 27 & 0.068 & 0.892 & 0.1 & 0.03 & $\mathrm{~B} / \mathrm{D}$ & 0 & $\mathrm{~B} / \mathrm{D}$ & 0.01 \\
\hline $\mathrm{BH} 5$ & 8.5 & 63.9 & 28 & 0.073 & 0.863 & 0.01 & 0.05 & 0.01 & 0 & $\mathrm{~B} / \mathrm{D}$ & 0.01 \\
\hline mean & 7.96 & 47.75 & 27.05 & 0.1586 & 0.8764 & 0.04 & 0.033 & 0.01 & 0.02 & 0.017 & 0.013 \\
\hline $\max$ & 8.5 & 68.9 & 28 & 0.762 & 0.896 & 0.1 & 0.05 & 0.01 & 0.04 & 0.017 & 0.02 \\
\hline stdev & 0.377 & 13.806968 & 0.684 & 0.21348 & 0.017 & 0.01 & 0.02 & 0.01 & 0.01 & 0.017 & 0.01 \\
\hline $\min$ & 0.377 & 13.806968 & 0.684 & 0.06 & 0.017 & 0.052 & 0.015 & 0.01 & 0.02 & 0.01 & 0.006 \\
\hline skew & -3.063 & -0.49131613 & -3.176 & 2.249763 & -1.613 & 1.732 & 0.935 & & 0.94 & & 1.732 \\
\hline
\end{tabular}




\subsection{Stiff Diagram}

Fig. 4 shows the geographic distribution of the stiff diagram across the study area that passed through Oke- oka and Iwaro oka. The polygonal shape graphical representation of water chemical analyses showing major cations is plotted on the left and anions on right; which is expressed in milliequivalents per litre on the left side and right side of the zero axis. Ionically related waters have shown the flow path and the ionic composition of water body changes over space and /or time. The water chemistry is dominantly anionic controlled towards the North eastern and Eastern part as well as less cationic in the Southwestern and western part of the study area (Fig.4).

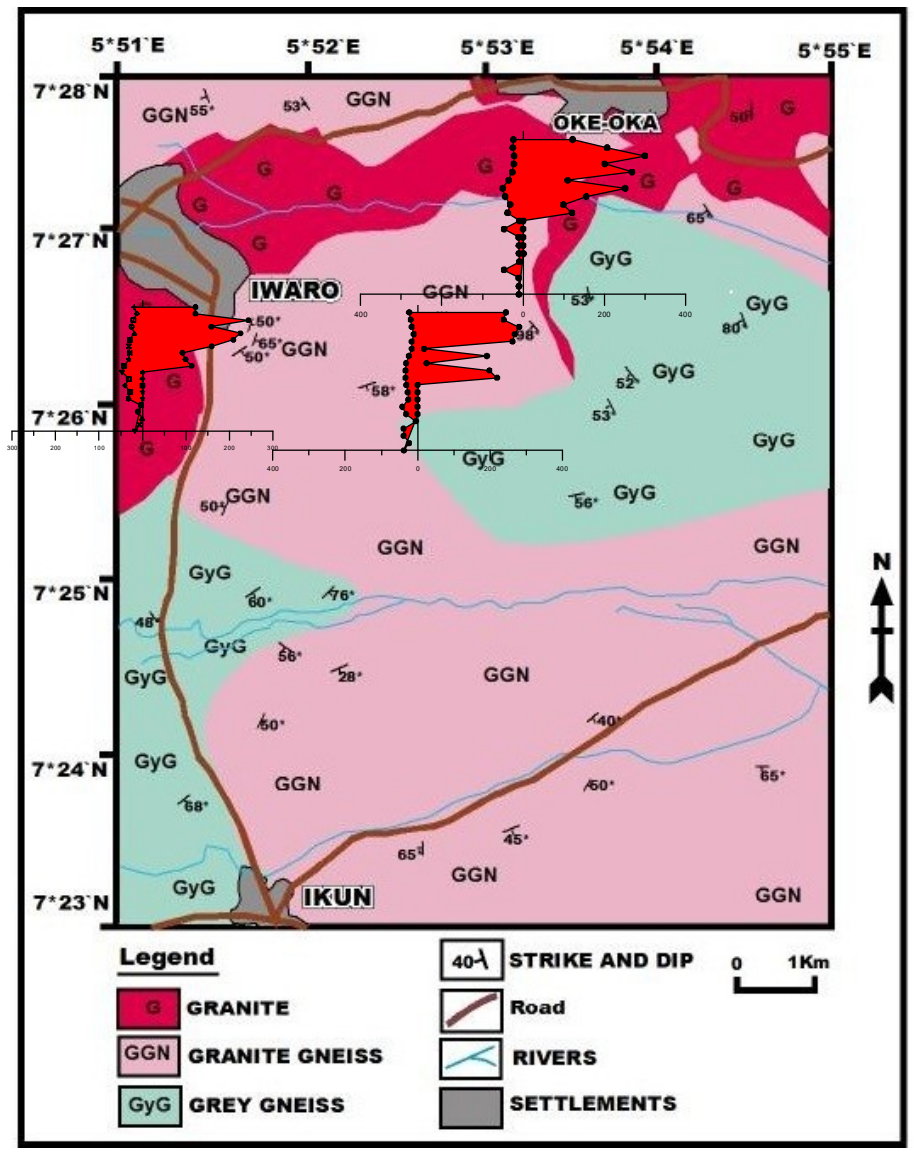

Figure 4. Geological map of the study area showing the stiff diagram.

\subsection{Radial Plot of Cations and Anions}

The direct comparison of various ionic samples values is against each other, according to standard measurement. The circular plot allows comparison based on shape of each section of the plot in terms of wind speed and velocity of ionic concentration and transportation due to their mineral availability (Escolero et.al 2005; Garcia et.al 2007)

\subsection{Water Facies}

Hydro chemical facies interpretation is a tool for determining the flow pattern, origin of chemical spices of ground water masses (Srinivasamoorthy and Vasanthavihar, 2008). The Piper diagram (Piper, 1944) is used to deduce hydro chemical facies. The classification can be achieved by the plot of physico chemical parameters of the water samples in the study area using Piper trilinear diagram in Fig.6. In this study, water classification has revealed $(\mathrm{CaCl})$ as the predominant water type, with reference to 
(Amadi, 1987), this type of water is typical of the Nigerian basement terrain, limited mixing and perhaps reflecting a primary stage of evolution of its groundwater system. Also, (Tijani, 1994) reported such chemical composition to be due to the dissolution of silicate minerals in the bedrock and aluminosilicates in the weathered regolith. The observed hydro chemical facies were $\mathrm{NaCl}>$ mixed $\mathrm{CaMgCl}>$ mixed CaNaHCO3 > CaHCO3. Piper's diagram (Fig. 6) shows the dispersion of the different cations $\left(\mathrm{Na}^{2+} \mathrm{Ca}^{2+}, \mathrm{Mg}^{2+}\right.$ and $\left.\mathrm{K}^{+}\right)$and anions $\left(\mathrm{HCO}_{3}^{-}, \mathrm{Cl}^{-}\right.$and $\left.\mathrm{SO}_{4}{ }^{2-}\right)$ contents in the groundwater samples, which indicates the origin of groundwater and the source of their dissolved salts and clarifies different processes affecting groundwater characters (Piper, 1944). Mixing of water from different sources or evolution pathways can also be indicated by this diagram (Freeze and Cherry,1979; Chidambaram and Karmegam , 2011). Plotting the groundwater samples on the Piper's diagram shows that most of the hydrochemical facies in this area fall in the field of $\mathrm{NaCl}$ type (75\%) with major CaNaHCO3 type (Samples No.1 and 2) and CaCl type (Sample No. 16). The distribution of cations tended to be clustered in the ternary diagram and was dominated by $\mathrm{Na}$ and $\mathrm{Ca}$. The facies are mainly mixed and $\mathrm{NaCl}$ facies indicate prolonged water- rock interaction and matured stage of water condition. Relative to the geology of the area, a similar deduction may be inferred with this water type since the study area is predominant by basement rocks; mainly granites, migmatite and gneisses which are composed essentially of mica, quartz, feldspars and other accessory minerals.

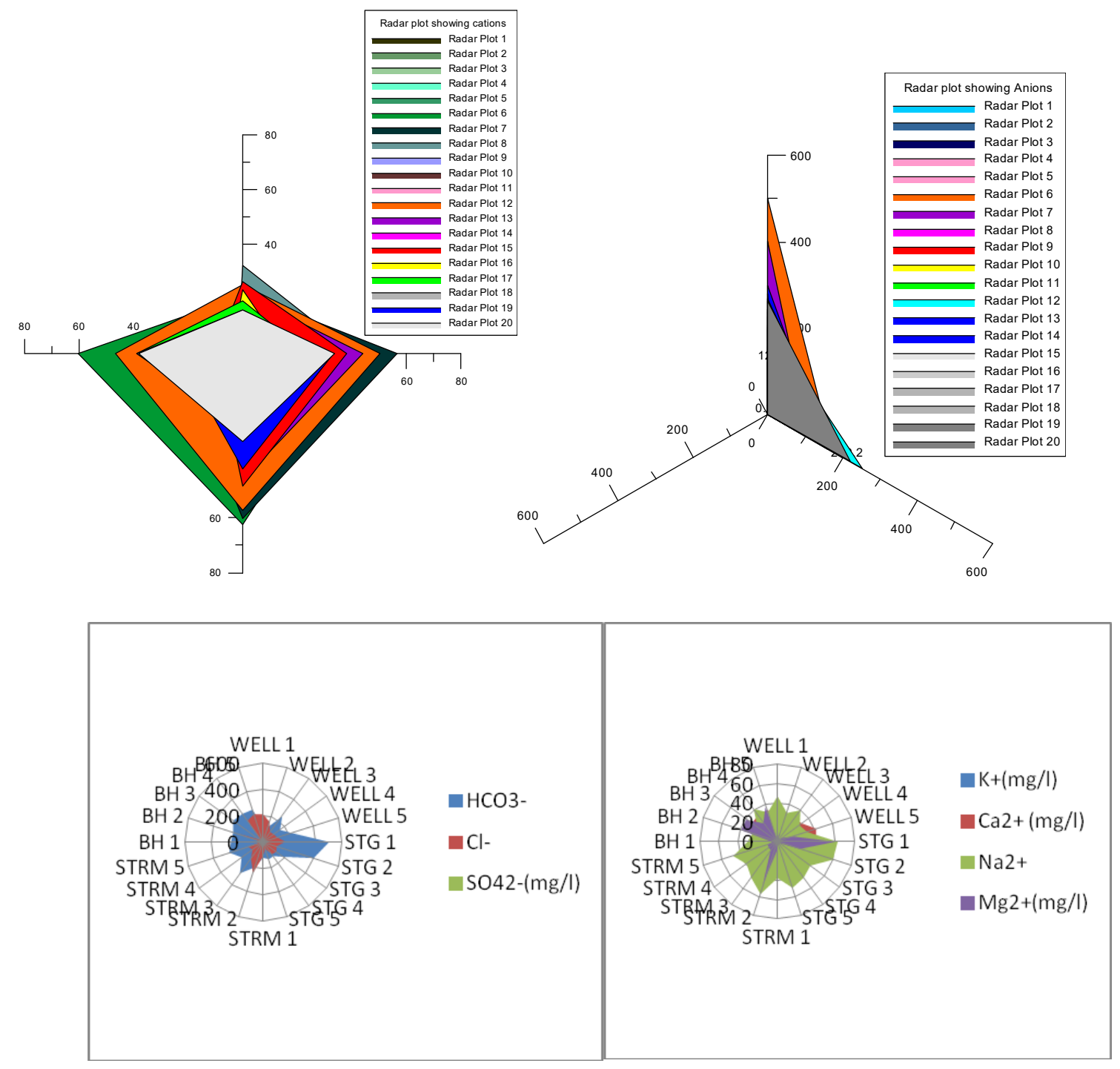

Figure 5. The radial plot of cations and anions in the study area. 


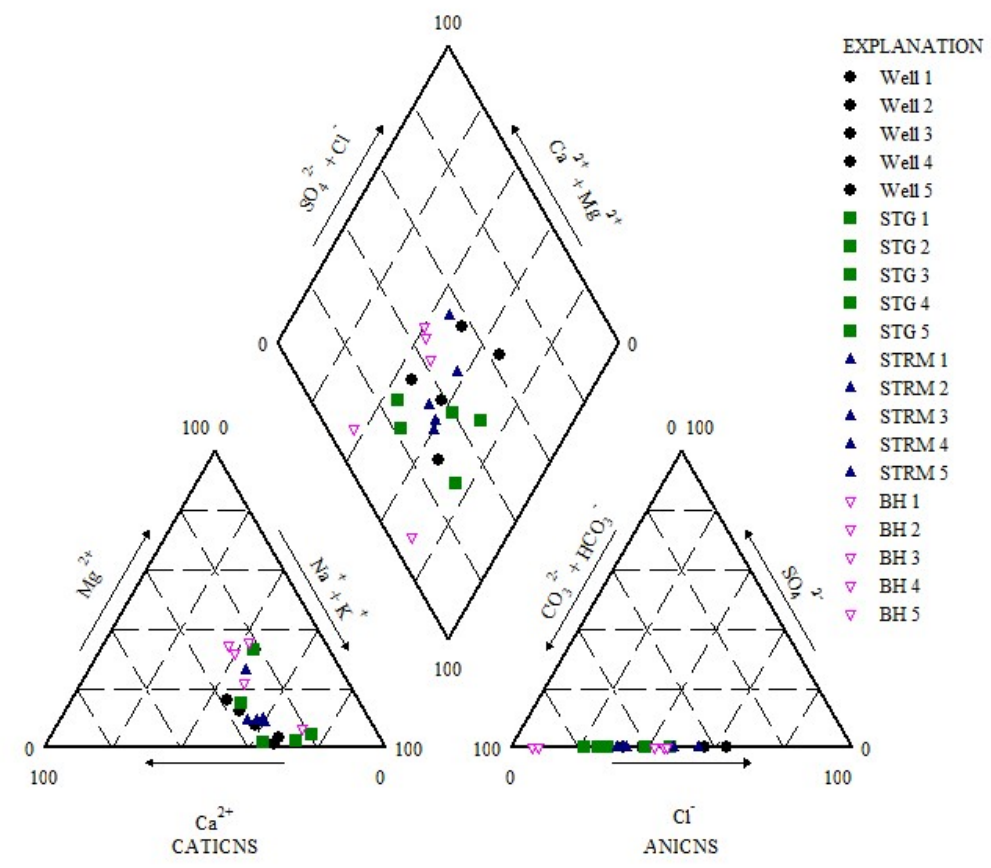

Figure 6. Piper diagram for major ions in the study area.

\subsection{Whisker Box Plot}

Box plots of the chemical concentrations of water resources show that $\mathrm{HCO}_{3}^{-}, \mathrm{Cl}^{-}$, had the largest variability (Fig. 7) and show a difference between the median and maximum values. The wide range of values from 122 to $500.2 \mathrm{mg} / \mathrm{l}$ in the $\mathrm{HCO}_{3}{ }^{-}$might have been attributed from sources like atmospheric $\mathrm{CO}_{2}$ and soil organic materials while $\mathrm{Cl}^{-}$content, 17.73 to $251.69 \mathrm{mg} / \mathrm{l}$ is the result of variations of its sources which may come from the weathering and subsequent leaching of felspathic rocks to clays and/or from agriculture fertilizers. Generally, the weathering of silicate rocks and anthropogenic activities are major sources of ions in water resources. If evaporation is the key process in water chemistry, then the $\mathrm{Na}^{2+} / \mathrm{Cl}^{-}$ratio would be unchanged. If halite dissolution was the main source of $\mathrm{Na}^{2+}$, the $\mathrm{Na}^{2+} / \mathrm{Cl}^{-}$molar ratio should be approximately equal to 1 . Values greater than 1 typically indicate that $\mathrm{Na}^{2+}$, is released from a silicate weathering reaction (Meybeck, 1987).

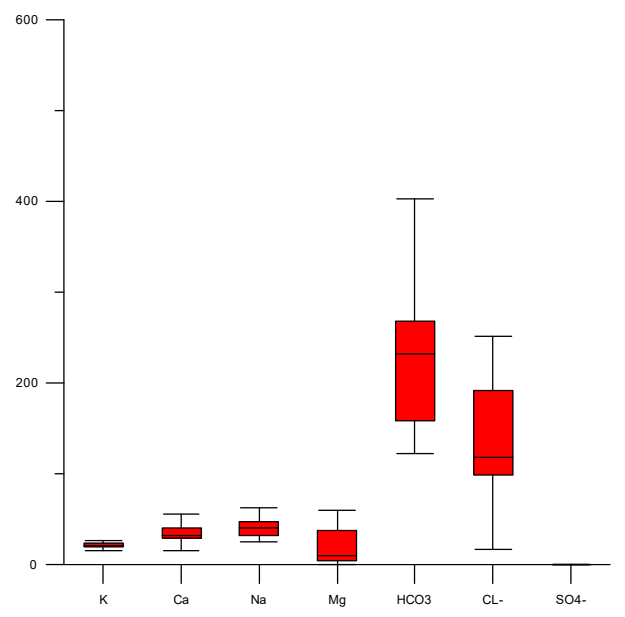

Figure 7. Whisker-Plot for major ions in the study area. 


\subsection{Silicate Weathering and Solute Distribution}

Silicate weathering is one of the key hydrogeochemical processes controlling the major ions chemistry of the water resources especially in crystalline terrain (Mackenzie and Garrells, 1965). The mechanism of silicate weathering can be understood by estimating the ratio between $\mathrm{Na}^{2+} \mathrm{K}^{+}$and total cations ( $\mathrm{TZ}+$ ). Majority of samples in the study area plot above the trend line $\mathrm{Na}^{2+} \mathrm{K}^{+}=0.5 \mathrm{Tz}+$ Fig. 8 signifies the contribution of silicate weathering due to the abundance of $\mathrm{Na}+$ and $\mathrm{K}^{+}$in groundwater (Stallard, 1995). The scatter plot for $\mathrm{Na}^{2+}, \mathrm{Ca}, \mathrm{Mg}, \mathrm{HCO}_{3}, \mathrm{Cl}^{-}, \mathrm{SO}_{4}^{-}$indicates the clustering of sample points with reference to equiline. Fig. 8b signifies the dominance of $\mathrm{Na}^{2+}, \mathrm{Mg}^{2+}, \mathrm{Ca}^{2+}, \mathrm{K}^{+}$cations in the water resources samples of the study area. Further in the scatter plot is $\mathrm{Cl}^{-}+\mathrm{HCO}_{3}{ }^{-}$the samples clusters above the equiline except $\mathrm{SO}_{4}^{-}$fig:4(c) indicating the dominance of alkaline earth over sulphate, signifying the process of silicate weathering in the study area. In the scatter plot for $\mathrm{Na}^{2+}$ vs. $\mathrm{Cl}^{-} \mathrm{Fig} .8$ majority of samples fall below the 1:1 equiline line, signifying the dominance of $\mathrm{Na}^{2+}$ derived from the silicate weathering from the litho units and minor inferences along the $\mathrm{Cl}^{-}$zone might be due to the anthropogenic activities (Srinivasamoorthy and vasanthavihar, 2008)

\section{Conclusion}

The water types using stiff diagram are useful in determining flow paths, recharge areas and communication between fracture networks within the study area. $\mathrm{NaHCO}_{3}$ is dominated by $\mathrm{Na}^{2+}$ and $\mathrm{HCO} 3$ from the dissolution of plagioclase and cation exchange of $\mathrm{Ca}$ for $\mathrm{Na}$ and is most evolved of the waters and $\mathrm{Ca}^{2+}$ and $\mathrm{HCO}_{3}$ easily weathered carbonates and represents recharge water. The dominance of cations like $\mathrm{Na}, \mathrm{Ca}, \mathrm{Mg}$ and lower $\mathrm{K}$ indicates the significance of silicate weathering and the resistance of potassium minerals to weathering and the concentrations of $\mathrm{SO}_{4}$ might have been derived from sources like agricultural influences since no dominant litho units for the contribution of the same have been identified in the study area. The source for $\mathrm{HCO}_{3-}$ might have been attributed from sources like atmospheric $\mathrm{CO}_{2}$ and soil organic materials. The sources for ions like $\mathrm{Cl}$ - and $\mathrm{NO}_{3}$ might have been derived from anthropogenic activities like agricultural influences. The water facies observed were $\mathrm{NaHCO}_{3}, \mathrm{Ca}-\mathrm{Na}-\mathrm{HCO}_{3}, \mathrm{Ca}-\mathrm{HCO}_{3}$ and $\mathrm{Ca}-\mathrm{Mg}-\mathrm{Cl}$. The water stability mainly fall in kaolinite field indicating the effective dissolution of silicates from feldspar group of minerals. The ionic ratio plots suggest silicate weathering, carbonate dissolution and ionic exchange processes to be activated in the study area. Increase in SI of minerals along the water resources flow path signifies the influence of litho logical sources for the alteration in the water chemistry.

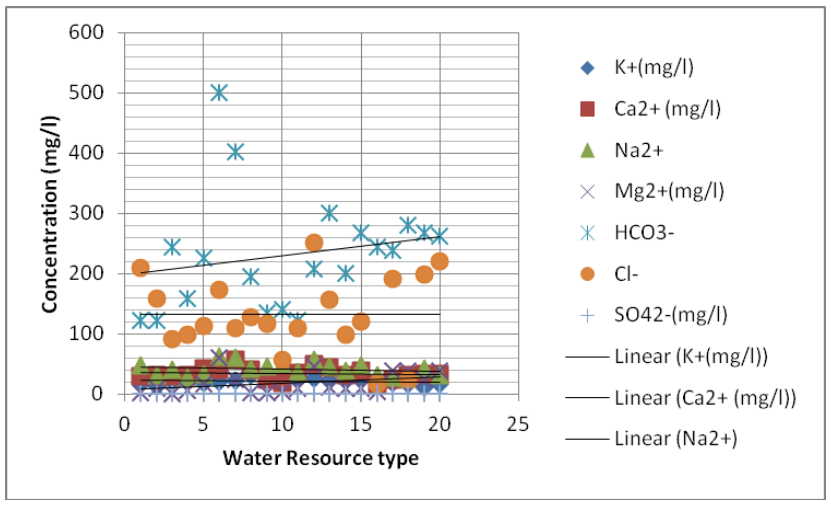

Figure 8. Scatter plot for major ions in the study area

\section{References}

1. Ademilua, A Geoelectric and Geologic Evaluation of Groundwater potential of Ekiti and Ondo States, Southwestern, Nigeria. Unpublished M.Sc.Thesis, Dept. of Geology, Obafemi Awolowo University, Ile-Ife, Nigeria. 1997, p. 1-67. 
2. U.M.P. Amadi, Mixing phenomenon in/groundwater system and its relevance in water quality in Nigeria. In: K. Iwugo(ed). A paper presented at the $2^{\text {nd }}$ annual symposium/conference of Nigeria water sanitation association, 1987, p. 17.

3. APHA, Standard methods for the examination of water and wastewater,21st edn. American Public Health Association, 2005: Washington DC, USA. 1302p.

4. R., Batmanghelid, Water and its Vital Role in the Health of a Water Starved Society. US National Research Council, Food and Nutrition Bureau, 2009, (2) p. 26-73.

5. R., Boss, Water for People, Water for Life. United Nations World Water Development Report. 2004, p.102-117.

6. D. B. Botkin, And E.A. Keller, Environmental Science: Earth as a Living Planet. 1998: New York. (2nd edition) John Wiley \& Sons Inc. p. 472-476.

7. S. Chidambaram, and U. Karmegam, Significance of saturation index of certain clay minerals in shallow coastal groundwater, in and around Kalpakkam, Tamil Nadu, India.2011.

8. L. D. Edungbola. and S.O. Asaolu, A Parasitological Survey: Onchocerciasis in Babana District of Kwara State, Nigeria. American Journal of Tropical Medicine \& Hygiene. 33 (999): p.1147-1154, 1984.

9. A.A. Elueze, Journal of Minerals and Materials Characterization and Engineering, 1997, 2(4) p.39-45

10. Escolero. Et. al. Geochemistry of the Hydrogeological Reserve of Meridia, Yucatan, Mexico. Universidad Nacional Autonoma de Mexico. 2005.

11. E. W. Foel, and R. A. Nenneman., How Peace came to the World. Cambridge. MIT Press. 1986, p. 112-121.

12. R.A. Freeze,. and J.A. Cherry., Groundwater. 1979: Prentice Hall, New Jersey

13. A.O. Jayeola, A.C Ogunyele, and J. Dogo., An investigation on Groundwater Chemistry from Geologic Controls on Water Sources around Ikare-Akoko area,southwestern Nigeria. The international journal of Sciences 83 Technoledge, 2(7), p. 140-148, 2014.

14. Garcia et. al. Effects of Wind on Background Particle Concentrations at Truck Freight Terminals. J Occup Environ Hyg. 2007.

15. G., M.J. Jiang, Noonan, G.D., Buchan, and N. Smith., Transport of Escherichia coli through variably saturated sand columns and modeling approaches. Journal of Contaminant Hydrology, 93(1-4), 2-20, 2007.

16. S. N. Kulshreshtha, ,A Global Outlook for Water Resources to the Year 2005. Water Resources Management. 12(3), p.167-184, 1998.

17. Mcfarlane, British Journal of Medical Psychology,1989 62(1), p. 81-90

18. D. S.McFarlane, J. A. Cherry, R. W. Gilham, and E. A., Sudicky, "Migration of Contaminants in Groundwater at a Landfill: A Case Study," Journal of Hydrology, 1983, 63( 1-2), p.1-29._doi:10.1016/0022-1694(83)90221-4

19. M. Meybeck., Global chemical weathering of surficial rock estimated from river dissolved loads. Amer. J. Sci., 287, p.401-428, 1987.

20. G. J. Miller, Environmental Science Sustaining the Earth. California (3rd Edition) Wadsworth Publishing Company. 1992, p.232-265.

21. T. D. Muyi, Water and the Body. Daily Sun. Tuesday, August 7, 2007 edition p. 3

22. NWRI, Borehole completion report at ABUTH Hostel,Groundwater Research Department, National Water Resource Institute, Kaduna, Nigeria, 2002.

23. T.H.T. Ogunribido and O.O. Kehinde Philips., Statistical Analysis for the Assessment of Hydrogeochemistry in Agbagbu Area, S. W. Nigeria. Processing of the Environmental Management Conference, Federal University of Agriculture Abeokuta, Nigeria, 2011.

24. M.O. Olorunfemi, and S.A. Fasuyi, Aquifer Types and the geoelectric/hydrogeologic characteristics of Part of the Central Basement Terrain of Nigeria (Niger State). Journal of African Earth Sciences, ,16(3), p.309 -317, 1993

25. A.M. Piper, A graphical procedure interpretation of water analysis trans America geophysical union, 1994, 25, p.914-925

26. M.A. Rahaman, A review of the basement Geology of southwestern Nigeria; in Geology of Nigeria, Kogbe C.A. (ed) Elizabethan publication co. Lagos, 1976, p.4-48

27. M.A., Rahaman, Recent advances in the study of the Basement Complex of Nigeria in P.O. Oluyide, Precambrian Geology of Nigeria. Geolo.sury. Nigeria Publ., 1988, p.11-43

28. M.A. Rahaman, and O.O.Ochan., On Relationships in the Precambrian Migmatitic Gneisses of Nigeria. Jour. Min. and Geol, 1978, 15(1), p.23-32 
29. K. Srinivasamoorthy. and M., Vasanthavihar, Identification of major sources controlling groundwater chemistry from a hard rock terrain - A case study from Mettur taluk,Salem district,Tamil Nadu,India, 2008.

30. R. F. Stallard, River chemistry, geology, geomorphology and soils in the Amazon and Orinoco basins. In : The chemistry of weathering, J. I. Drever (Ed.), D. Reidel publishing company, 1995, p.293-316.

31. M.I.N. Tijani, Hydrogeochemical Assessment of Groundwater in Moro area of Kwara State, Nigeria Environment Geology, 24 p.194-202, 2004.

32. K. Venkatesharaju P. Ravikumar., R.K. Somashekar., and K.L. Prakash., (2010), Physico-chemical and Bacteriological Investigation on the river Cauvery of Kollegal Stretch in Karnataka, Journal of science Engineering and technology, 6(1), p.50-59. 2010.

33. W.O. Odiette, Environmental Physiology of Animals and Pollution Diversified Resources. Lagos. 1999, p.187218. 